(REVIEW ARTICLE)

\title{
Urbanization and Ikwerre development
}

\author{
Maduawuchi Elem* \\ Sociology Department, Faculty of Social Sciences Ignatius Ajuru University of Education Rumuolumeni, Port Harcourt, \\ Rivers State.
}

Publication history: Received on 15 November 2020; revised on 12 December 2020; accepted on 14 December 2020

Article DOI: https://doi.org/10.30574/wjarr.2020.8.3.0423

\begin{abstract}
The work examines if urbanization which took place within Ikwerre land in Rivers State produced Ikwerre development. The work observed that urbanization did not only removed Ikwerre people from their land; their natural heritage, but also gave them proximity advantage which should have given them easy access or advantage to develop at least more than other ethnic groups in Rivers State. On the contrary, other ethnic groups appears to have had a better head start than Ikwerre people even when their land is still intact and that urbanization eroded thoroughly Ikwerre culture especially their language. Based on these, the work recommended a re-invention of Ikwerre culture for development and peaceful opposition to forceful acquisition of Ikwerre land by the government among others.
\end{abstract}

Keywords: Urbanization and Development

\section{Introduction}

Society is always in a state of flux as social contradiction is natural. In this regard, urbanization is a cardinal driving force driving the metamorphosis, and each time, it successfully propels change, which often manifests in cultural diffusion urbanization also infuses into the system a new phenomenon which generally provides the host society where urbanization is taking place, favourable developmental advantages ahead of other distanced society. This early exposure to urbanism, it is believed, is one reason why the Yoruba nation in Western Nigeria is considered for more developed (especially in education), has more manpower (both quantity and quality manpower) than other ethnic groups and will continue to in the nearest future. This developmental head start of indigenous societies hosting urbanization is more apparent in third world countries where development generally is urban biased. Going by proximity advantage, it is believed that the host communities should be the very first beneficiary of such developmental opportunity as such, they should be able to marry the new changes with their culture (the primary basis for development) to their advantage. It is on this basis that this work intends to establish if the indigenous Ikwerre people, the owners of Port Harcourt are actually developed given their age-long urban advantage which they have ahead of other ethnic groups and the abundant opportunities available to them as landlords in Port Harcourt, Nigeria.

\section{Conceptual clarification}

Urbanization is seen in two senses; demographic sense and a social process. The former is concerned with redistribution of people to the extent that such redistribution has resulted into heavy concentration of people in that area than other areas. In this sense, urbanization is closely linked with movement of people of peoples' settlement pattern, usually rural to urban and or urban to urban, in a given area. As a social process, urbanization means the diffusion of people's normative system, values attitudes and behavior due to demographic increase. In this context, urbanization means change in indigenous Ikwerre cultural values due to increasing population concentration in Ikwerre land.

\footnotetext{
${ }^{*}$ Corresponding author: Maduawuchi elem

Sociology department, faculty of social sciences ignatius ajuru university of education rumuolumeni, port harcourt, rivers state.
} 
Embolden Ikwerre Development- Ikwerre development means a deliberate, joint and continuous efforts by Ikwerre people to confront environmental factors (physical and social environment) that hinder the attainment of Ikwerre higher standard of living. Social environment which includes: class, religion, ethnicity etc are socially created. Physical environment is concerned with natural forces or materials created by God. They include the hills, valleys, rivers, seas, terrain, etc. Overcoming these environmental factors are imperative because environment determines the people's cultural contents. So Ikwerre development is one that is tailored towards overcoming all the limitations posed by their environment in a bid to attaining prompting Ikwerre cultural values or to attaining meaningful cultural life. Learning on this, Ikwerre development should promote Ikwerre language, Ikwerre food culture, socio-economic activities and other social activities that define Ikwerre people as a distinct people on a sustainable basis.

\section{Ikwerre people: Background record}

Ikwerre people also called Iwhuruohna (Elem, 2020), Nsirim 2020), Tasie, 2008), Lawrence-Hart 2020 are a distinct ethnic group and the most populous culture in Rivers State, Nigeria. Ikwerre people are the traditional owners of Port Harcourt, the capital city of Rivers State. They occupy four local government area (Obio/Akpor, Port Harcourt, Emohua and Ikwerre local government area) out of the 23 local government areas that makes up the state. Ikwerre people are sandwiched in the west by the Ogba-Egbema, Ekpeye and Abua. In the south by the Okrikas and Kalabaris. In the north by the Etche and Imo State, while in the East they share boundary with Eleme and Oyigbo people. By their spread, the Ikwerres are strategically blessed, they play host to over sixty per cent of companies in Rivers State. This includes educational institutions like University of Port Harcourt, Rivers State University, Elechi Amadi Polytechnic, Ignatius Ajuru University of Education, and Rivers State College of Health Science and Technology.

Ikwerre socio-economic and socio-political activities are simply remarkable. They are predominantly agrarian farmers and fishermen and are located in both marine ecosystem and alluvial land. Given their vegetation, the people are famous in hunting expeditions, palm wine tapping, palm fruit gathering, craft making, trade and palm harvesting, brewing of local gin (Omemayagbeke) from raffia palm, production of palm oil (Ome Monowiri) from palm tree, production of palm kernel oil (Ome Mono-Oknu) from palm tree fruits etc. Farming (Enruuvil or Ekwu) is the most spectacular of all their economic activities as it is the chief occupation of the people. They are noted in the production of garri, (cassava flour, a staple and compulsory food that cannot be resisted in any Nigerian menu. Just like their garri, Ikwerre vegetable is currently the most priced of all the other vegetables from other ethnic groups in Nigeria. Besides these, the Ikwerres produce different variety of yams too, and they practice shifting cultivation type of farming. From these economic activities, hunger is far away from the people.

Ikwerre economic life is basically communal. For example, apart from Ngweta, (a traditional mutual labour hiring method, women use to work for each other or one another's farm on rotational basis without money for the labour, but food or provisions which the host provides for the other farmer or farmers) and hiring of labour, is not very common practice. From laborers are from relatives; in-laws, friends etc. In Ngweta, the farmers are free to harvest pepper, vegetables, fetch firewood and harvest Okro from their host farm. The act of group farming in Emohua for example is greatly enjoyed by the Nne-Ohna and Ele-Eruurie. Nne-Ohna is a member of the Council of Chiefs also called the Owhor or title holders. Nne-Ohna must be a man and he alongside other ohnas, rule with the paramount ruler. A collection of Ohna is called Ele-Ohna. Ele-Eru Urie are the family heads. By their status, they are entitled to free farm work. This act is equally replicated during harvesting of yam which is seen as fun to all groups mentioned above as their will be so much to eat. To reciprocate their gesture, the chief gives out tubers of yam to all those who participated in the harvest. The same communal living is equally seen during burials, child birth, fishing and building of new or fallen houses.

Politically, the Ikwerre are republican, Ikwerre leadership is patriarchal and gerontocractic (Worlu, 2014). In this political arrangement, only the eldest son of each family exercises the leadership authority or have access to the throne. In this regard, the Ohna, even the Nne Eru Urie, is seen as one who acts as intermediary between the living and the dead. As such, should have sufficient native wisdom and always standing for the truth and justice.

At the apex of Ikwerre political leadership is the paramount ruler. In most Ikwerre communities, access to the throne is through consultation from the ancestors. Below this group is the family chiefs who preside over family matters. The family chief is assisted by a lieutenant, who will coordinate when the Nne Eru-Urie is absent. Ascension to the throne is determined by age. In Emohua and most Ikwerre communities no bastards can ascend these offices.

Of importance in Ikwerre leadership is the age grade, a group of people born within three- years age bracket. They are essentially the community labour force, police and the custodian of community custom. They can adjudicate on matters concerning their members. Such matters include infidelity among members' wives and any member of the age group. 
Ikwerre cosmology is crowded with believe in spirit, good and bad spirits who possess the powers to monitor the activities of man on earth. These spirits are God Almighty (Chiokike), Ancestors, (dead fathers) and deities, agents of demon). The Ikwerre belief in spirit is demonstrated when misfortune happens; the people quickly go out to find out from the deities what is responsible. In the same vein Ikwerres spiritualize the earth, thus the earth is respected as it is capable of bringing good and bad. This is why an Ikwerre man can exclaim; Eli/Ali Ikweo ( a call on the earth to prevent such evil from taking place) at the occurrence of a near-mishap (Lawrence Hart (2020). The sacredness of the each is equally seen when an evil man is buried. Such a man is rejected by the land irrespective of the years such a corpse has stayed on the ground. The rejection here is confirmed as the corpse will not discompose, even the clothes and the casket will remain the same; fresh, the way it is, when the person was buried. Such a corpse will be exhumed by the earth, not by any human force. Such a person will only decompose if he/she is thrown into the evil forest.

Equally interesting is Ikwerre entertainment which is revealed in Eregbu dance, Ikwerre wrestling, and other musical groups like: Jimmy Conter, Majority, Tufiakwa and Promoter Eze. These musical dance are irresistible as their tracks are full of moral lessons. Ikwerre waist dance is simply unique among other ethnic groups in Rivers State. Wrestling is used to measure great warriors and also attracts great honour.

The implication of these cultural values are monumental, firstly, it is the basis for the sustained peace and development the Ikwerres enjoy. for example, the hereditary nature of chieftaincy thrones and the use of spiritual inquiries to determine who will ascend to chieftaincy thrones eliminate chieftaincy tussles. Secondly, the level of moral rectitude facilitates easy delivery of justice at all levels. Thirdly, communal living provides a good welfare system in all the diverse economic activities. Beside these, during burials, women come together to cook free food for visitors. They also contribute food items and fire-wood. The men whether from the family or not are committed to providing all necessary services for the burial free. In the same vein all palm wine tappers supply their wine, compulsorily for a token and sometimes free. In this way, the heavy burden of the burial is shared by all and reduced. All these account for the peace and development witnessed in the idea/traditional Ikwerre society before corruption came in, occasioned by urbanization. So the traditional Ikwerre man does not only have talent he acquires which are vital to conquering his environmental challenges. Such talents in addressing his needs. When a man learns to tap palm wine for example, he is aware that palm wine will be useful during burial and wresting contexts.

\section{Urbanization in Ikweere and Ikwerre development}

Idea urbanization substantially alters a people's way of life especially the indigenous people's lives. This is because modern cities over time, have become modern political power houses. Decisions, according to Ekpenyong (1999), are taken in the cities about levels of taxation and support for rural development. In all these, cities are unique because of their size, density and heterogeneity.

Urbanization in Ikwerre land is typical of African cities that evolved from or are midwifed by European colonialists adventure occasioned by capitalist expansion in Europe which created the need for external market. In Ikwerre's case, according to Worlu (2015) and Akani (2020), Port Harcourt, officially received its name in 1913 by Sir Fredrick Lugard, the then Governor General of Nigeria. The choice of Port Harcourt was necessitated by its natural habour which the colonialists discovered will be useful for seaport and railway infrastructure. The establishment of Port Harcourt initiated massive urbanization of Iwhuruohna communities. Consequently, according to Ofonagoro (1970) in Akani (2020) spectators, merchants, artisans, traders and the ruling class of Igbo extraction invaded Port Harcourt. Confirming the Saro-Wiwa (1989:175) in Akani (2020) observe thus:

"Port Harcourt was from the beginning a cosmopolitan community consisting of labourers, employees of trading firms, traders, teachers, clergy man, from parts of Nigeria and other West African Towns, Sierraleone, Ghanaians, Togolese as well as Syrians and Indian Shopkeepers. P. 75"

Beyond this, the emergence of oil and gas resources and government urban bias or over preference on Port Harcourt heightened the speed of urbanization in Ikwerre land. For example, all the military base: Army, Navy and Air Force are in Ikwerre land, all the oil firms and the servicing firms have their major, if not all their head offices, in Ikwerre land. These include Nigeria Television Authority, Former Radio Rivers, Nigeria Industrial Training fund in Ozuoba, the list is endless. In the same manner, the state government over the years is not insulted form this urban bias development. As it stands, virtually all companies and institutions owned by Rivers State government are situated in Ikwerre land. This makes Ikwerre land the epic centre from all manner of persons, who wants meaningful life. 
Over time, Port Harcourt has to experience unguarded invasion by people, thus there is a deficit between the demand for social services especially housing and the demand for housing. This made the poor, who constitutes greater proportion of the population of emigrants to develop make-shift settlements in all this eco-environment, thus all waterfront becomes congested. With the growth and the congestion of waterfronts, the hitherto rich biodiversity of these environments are lost. The loss of the resource base is significant as it represents the loss of Ikwerre people's socio-economic value, life and norms,that defined Ikwerre people.

In order to direct development in Port Harcourt, subsequent governments over the years embarked on urban renewal programs. During the military era, Ndoki water side was upgraded with the false conception of building modern houses for the poor, the price of which is far from what the poor can afford. As a result, the people congregated in another location to form another slum. During Rufus Ada George's era most cultural sites in Ikwerre land like the shrine in Rumuokwuta junction and the Ojukwu Diobu shrine were destroyed. He even mapped out another land in Rumuosi area for a new phase of Government Reservation Area. As it stands today, the social boundary between Obio/Akpor, Port Harcourt and Ikwerre Local Government is difficult to identify. In these developmental drive, the Ikwerre people have witnessed the worst sacrilege in Rotimi Amaechi's tenure. He did not only demolish all the remaining existing water fronts in Port Harcourt, he acquired massive land for Greater Port Harcourt City (GPHC). The new city covers approximately 1,900 square kilometers (40,000 hectares) of land (Worlu, 2015). GPHC according to www.rirsna net in Worlu (2015) has the following objective, vision and opportunities.

"To transform the GPH Area into a world class city, internationally recognizes for excellence and the preferred destination for investors and tourists. To build a well-planned city through the implementation and enforcement of policies that will ensure the provision of first- rate infrastructure and delivery of quality services to enhance the standard of living and wellbeing of the people. This will be by building a modern city with twenty-four hours electricity supply bulk sewage system, network of good roads/streets, public transportation system, storm water management, waste disposal systems, surveillance systems, well laid out residential, commercial and industrial areas, parks and even gardens. The opportunities that the new city will provide to would be investors will include, but not limited to power generation and transmission, housing project, urban transportation system, water supply and reticulation, exciter. Importantly, funds for the projects will be provided by Rivers State Government (RSG) and Public Private Partnership (PPP) initiative."

This sustained government attitude toward acquiring Ikwerre land is disturbing. Firstly it has led to the loss of Ikwerre socio-economic activities. Wosu (2012) has observed that the invasion of Ikwerre ancestral land led to the sale of the land by Ikwerre people and that you have become house agents as an economic way of getting succor in the present state. Secondly, given the speed in urban growth in Rivers State, Ikwerre people in Port Harcourt City have been subsumed by the diverse culture in the area. Today, it is very difficult for one to meet and identify an indigenous Rebisi person in what is known today as Port Harcourt, whether around the old township or the Diobu areas (Worlu, 2015). Like any other land acquisition, Rivers State Government paid a paltry sum of three hundred thousand Naira (300,000) only for a plot (Worlu, 2015). As observed above, Ikwerres are patrilineal, farm land can be given to women, but in this ease, women who constitute significant population are neglected. This same plot of land, if sold by the individual cannot be less than two million per lot.

Beside this, the government also embarked on expensive dualization of roads in Port Harcourt which affected ancestral homes and buildings. Of course, like in other past cases, the Rumular payment for example is N300,000 per annum. In this 2020 budget, Rivers State government, aside other projects have started construction of three overhead bridges and expansion of Ikwerre Road to the Airport in the state. The impact of this in Ikwerre family lands and ancestral landmarks are better imagined. This generally fear of losing land has pushed communities like Ipo, Omagwa, Igwuruta, Omademe, which hitherto, are rural areas to start the sale of land. Today in these communities, different land speculators have acquired large areas of land and have built estates for rent. By this, Ikwerre people (apart from Emohua community with long history of security) have lost Port Harcourt City, Obio/akpor and about sixty percent of farm lands in Ikwerre local government area to urbanization.

In the face of these, can one claim that the current hyper-urbanisation has brought check about development in Ikwerre? Several studies from Dibia (2011), Okogbule (2018), Wosu (2012) etc. reveal a conspicuous deficit between the rate of urbanization and Ikwerre development. In these studies, especially in Dibia (2011) urbanization in Ikwerre has only produced tremendous Ikwerre growth, not Ikwerre development.

This is simply true as from the very beginning, the underlying impetus wasn't to elevate Ikwerre culture and Ikwerre people capacity to use their resources to bring about quantitative and qualitative improvement in all aspects of Ikwerre people's lives. Rather, European economic interest superseded Ikwerre's interest. The scenario has not changed, but 
has deepened in contradiction with the incorporation of the parasitic local ruling class to the existing western interest. Toda, seventy per cent of Ikwerre food is from other ethnic groups due to unguided urbanization in Ikwerre land. The massive infrastructural build up has grossly produced social disarticulation of Ikwerre culture due to the presence and the influence of other well developed cultures who are attracted to Port Harcourt because of the hyper-urbanization in the city. Ideal development means that, educational institutions for example, should lead to an improvement in the indigenous people's occupation including the Ikwerres and also teach them (the Ikwerre people) the processes of developing and refining their talents to improve the existing indigenous Ikwerre values to meet their needs on a sustainable basis. The evidence of growth not development is seen in the high rate of unemployment among Ikwerre youths occasioned by loss of land district from other ethnic groups who did not cede their land for infrastructural development like the Ikwerre's did. For example, the Ogoni's even when they rejected relocation of military base to Bori due to the fear of loss of land among other reasons can still boast of not less than ten (10) retired and serving senior military officers while the Ikwerres do not have up to four military officers given the arable land occupied by the Nigeria military in Ikwerreland. The lack of military personnel in Ikwerre and the abundance of same among other reasons accounts for why the Ijaws took all the military governorship slots given to Rivers State during the military era, yet not one piece of their land was given to the military by the Ijaws.

Beyond this, at least, given the proximity of educational institutions to the Ikwerres and the real meaning of development, one will expect more Ikwerre and the real meaning of development, one will expect more Ikwerres in school's sustenance (not death) of Ikwerre cultural values like Ikwerre language, dance, adages, folklores, stories and history. The loss of native customs and traditional values account for incessant land and chieftaincy disputes and near cases of identity loss. Today, most indigenous Ikwerre children are fluent in pidgin English- the adulterated English language not Ikwerre language. The death of a people's culture marks the end (death) of that society.

\section{Conclusion and Recommendations}

Clearly, the age long hyper-urbanization witnessed in Ikwerreland has produced growth, not development. It merely made available social infrastructure through excessive land acquisition without equivalent qualitative increase in the building of Ikwerre culture. The first option for Ikwerre development is re-invention of or a re-discovery of Ikwerre culture for development. This will entail an establishment of Ikwerre Research and Development Group. This body should comprise of Ikwerre with sound research knowledge/interest in Ikwerre culture, history and development. Equally important in this re-invention enterprise is the re-introduction of Ikwerre literature books, for now, at the primary school level. In this regard, Ikwerre literary scholars who are naturally gifted in literary works should be ready to produce short stories on Ikwerre culture and language. This development will help to bridge the cultural gap between the current generation and the coming ones. To achieve this, Ikwerre people should collaborate with other ethnic groups in Rivers State to put pressure on the Rivers Sate Government to do the same for the whole State. When this is sustained, these languages should be made one of the subjects in all ordinary level examinations in Nigeria just like Hausa, Yoruba and Ibo.

Similarly, Ikwerres should vehemently oppose forceful acquisition of Ikwerre land, in this, Ikwerre unity and leadership is vital as it is the secrete why Ogoni succeeded opposing the relocation of military base to Bori. So Ogbakor Ikwerre, Ikwerre Development Association, and other professional bodies should brace up to provide the needed leadership drive. Where this opposition is sustained, it will reduce the rate of urbanization and the speed of erosion of Ikwerre culture while allowing Ikwerre people to successfully invest on their land at their own pace.

In this regard, only Ikwerre songs and dances should be used during traditional events. Finally, there should be extensive investment in human capital of the Ikwerres. This way, Ikwerre will be able to meet all the privileges due them as specified in the Nigeria constitution and the Memoranda of Understanding (MOU) they entered with all the institution in Ikwerre land. In this, "Ikwerre Buotu" (Ikwerre is one) spirit, should drive employment opportunities available.

Where the very host Ikwerre community is not able to have the required person even in university admission, the next Ikwerre community should be approached for such opportunity if they have any. It is expendient for Ikwerre people to have viable Community Development Communities in all the communities hosting any institution in Ikwerre land who will aggressively pursue their interests in the MOU and renegotiate the existing ones where necessary. In doing this, the committees should ensure that Nigeria Local Content Law regarding host communities and their companies is followed. 


\section{Compliance with ethical standards}

\section{Acknowledgments}

I acknowledge the support of Mr Chinago Budnukaeku Alexander of Young Publishers League for his assistance to make this paper published. I appreciate your support and encouragement.

\section{References}

[1] Anale KA. Ethnography of Sub-Saharan Africa. Luckozim Nigeria, Port Harcourt, Nigeria. 2003.

[2] Dibia O. The challenge of Ikwerre development in Nigeria. Bilex Productions, Nigeria. 2011.

[3] Ekpenyong S. Elements of Sociology. African Heritage Research and Publications, Lagos, Nigeria. 2003.

[4] Elem M. Globalization and the twilight of Ikwerre culture in Akani A, and Mmejim, L.C. Iwhuruohua: A study of Ikwerre history. Yenegoa, Bayelsa State, Nigeria: Alabaster books (resources). 2020.

[5] Ekpenyong S. City in Africa. African Heritage publication. Lagos, Nigeria. 1990.

[6] Lawrence-Hart G. The place of religious value in Akani, C. \& Mmejim Iwhuruohna development in Iwhuruohna: A study of Ikwerre history Yenegoa, Bayelsa State, Nigeria: Alabaster books (resources). 2020.

[7] Nsirim K. Ikwerre youths and cultural heritage: The missing link. In Akani C. and Mmejim, I.C. Iwhuruohna: A study of Ikwerre history: Yenegoa Bayelsa State, Nigeria: Alabaster books (resources). 2020.

[8] Okogbule NS. Urbanization and Ikwerre culture in the 21st century. Paragraphics, Port Harcourt, Nigeria. 2018.

[9] Tasie ACM. Ikwerreland, culture and people. Port Harcourt, Nigeria: Prify Press Publishers. 2008.

[10] Worlu HN. Greater Port Harcourt City and biomass extraction by indigenous Ikwerre women on the environment. 2015. In Worlu HN, Eminike G. Ganger and Society Goldstones. Global Resources; Port Harcourt, Nigeria. 2014. 